\title{
Mobile Application for Asian Soybean Rust Tracking in Brazil
}

\author{
José Henrique Andreis ${ }^{1}$, Felipe Borella ${ }^{1}$, Willingthon Pavan $^{1}$, Carlos Amaral \\ Hölbig $^{1}$, Jaqson Dalbosco ${ }^{1}$, Cláudia Vieira Godoy ${ }^{3}$, José Maurício Fernandes ${ }^{1,2}$ \\ ${ }^{1}$ Universidade de Passo Fundo (UPF) \\ 99.052-900 - Passo Fundo - RS - Brazil \\ ${ }^{2}$ Empresa Brasileira de Pesquisa Agropecuária (EMBRAPA) \\ 99.050-970 - Passo Fundo - RS - Brazil \\ ${ }^{3}$ Empresa Brasileira de Pesquisa Agropecuária (EMBRAPA) \\ 86.001-970 - Londrina - PR - Brazil \\ \{pavan, holbig, 61779, jaqson\} @upf.br, andreis@ufl.edu, \\ claudia@cnpso.embrapa.br, mauricio.fernandes@embrapa.br
}

\begin{abstract}
Brazil is the second-largest soybean producer. With the arrival of Asian soybean rust in the Western Hemisphere in 2001, a considerable amount of resources has been allocated to understand and control this important yield-limiting disease. Due its rapidly dissemination, in 2004, the federal government led an effort to create the Asian soybean rust consortium, with the main goal of coordinating research activities involving public and private sector. This paper describes the development of a mobile application, designed to support the Asian Soybean Rust Consortium to monitor, in time and space, occurrences of Asian soybean rust in Brazil.
\end{abstract}

Resumo. O Brasil é o segundo maior produtor de soja do mundo. Com a chegada da ferrugem da soja no hemisfério ocidental em 2001, uma quantidade considerável de recursos foram alocados para entender $e$ controlar esta importante doença. Devido a sua rápida disseminação, em 2004, o governo federal uniu esforços e criou o Consórcio Antiferrugem, cujo objetivo principal seria de coordenar atividades de pesquisa envolvendo empresas públicas e privadas. Este artigo apresenta o desenvolvimento de um aplicativo móvel, projetado para auxiliar este Consórcio no monitoramento em tempo e espaço, de ocorrências de ferrugem asiática de soja no Brasil.

\section{Introduction}

Since the early twentieth century, when soybeans began to be produced and marketed in the United States, this crop has occupied a prominent place in agribusiness worldwide [Roberts 2006, Kim 2005]. In Brazil, this crop has been leveraged by various factors making it one of the most important crop established in the country. With the advance of soybean production in Brazil, there were also the emergence of serious diseases, causing significant damages, which can be avoided or minimized with efficient control and management of diseases [Esker 2007, Godoy 2015]. The Asian Soybean Rust, for example, if not early treated, can cause premature defoliation, preventing the complete 
formation of the grains and generating sharp reductions in productivity. Reports of production losses due to the disease have reached $75 \%$ in some regions [Yorinori 2005].

In this sense, the CAF (Asian Soybean Rust Consortium http://www.consorcioantiferrugem.net), consolidated by partnerships between universities, research institutions, laboratories and soybean producers, has strongly acted in Asian soybean rust monitoring spreading in Brazil, assisting producers to control the disease and reduce the risks.

\section{The Application}

Information technologies have been great allies of the CAF to obtain strategic information on disease dispersion and prevention. Considering the importance of fast identification of soybean rust to start an efficient control, minimize, or even avoid losses caused by it. Information technologies have also allowed the development of features that enable collaborative and online work among all actors involved in the management of the disease.

The development of a mobile version of the CAF has the goal of providing immediate access to the disease dispersion information to producers, directly from their smartphones. The CAF mobile application allows the easy visualization of the soybean rust dispersion in Brazil on disease dispersion maps. The map enable producers to become aware of the occurrence of the disease in their region and to anticipate the searching for infections on their fields, consequently minimizing the chances of great losses, which are very common in infections by Phakopsora pachyrhizi.

The application was developed using native programming languages and tools for the iOS platform (Swift, Xcode and iOS SDK) and Android platform (Android Studio and Android SDK). The app development follows the MVC (Model View Controller) software architecture patterns. Data are obtained by HTTP requests to a specific RESTful API written in Java and hosted on the CAF server.

Soybean rust infections are confirmed and registered in the system by 175 certified laboratories that make part of the Asian Soybean Rust Consortium and cover all soybean production regions in Brazil. The Figure 1 shows an interaction diagram between client (app), server, and certified laboratories, covering the entire system operation. JSON (JavaScript Object Notation) data-interchange format is used for the communication between the mobile app and the server REST API.
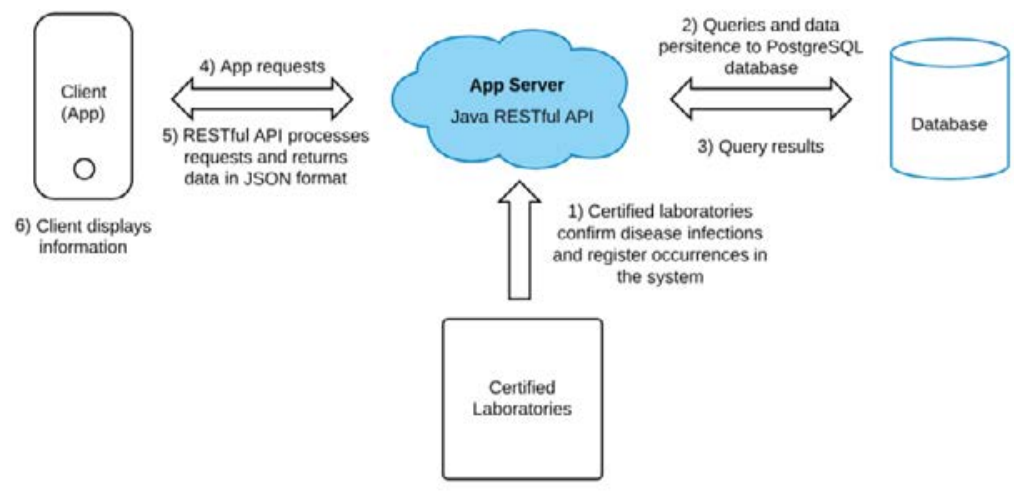

Figure 1. Interaction between client, server and certified laboratories 
Besides the disease dispersion map, the application also presents the data through a list for easy access and search for specific cities and occurrences. Either dispersion map and list interface allows the users to have access to detailed information about each registered occurrence, what can be used to be reviewed and compared, aiding producers decision making on the field.

\subsection{The Dispersion Map}

The main screen of the app is composed of a dispersion map, which aims to provide a general visualization of the disease dispersion. As shown on Figure 2, the current selected season is presented in the navigation bar, on top of the screen. In the central area, red dots represent the cities were occurrences were registered. Additional information such as the name of the city and total of occurrences are presented when the user touch on a dot (Figure 3). The dots have different sizes what are proportional to the number of occurrences allowing an easy perception of the most affected regions. Select previous seasons are also allowed in the system. Users can tap the navigation bar title to have access to a new interface where the seasons are presented allowing its selection and updating e the information on the map (Figure 4).

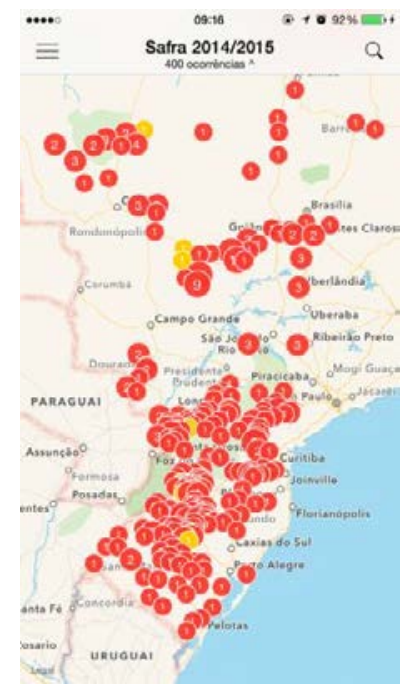

Figure 2. Map of dispersion

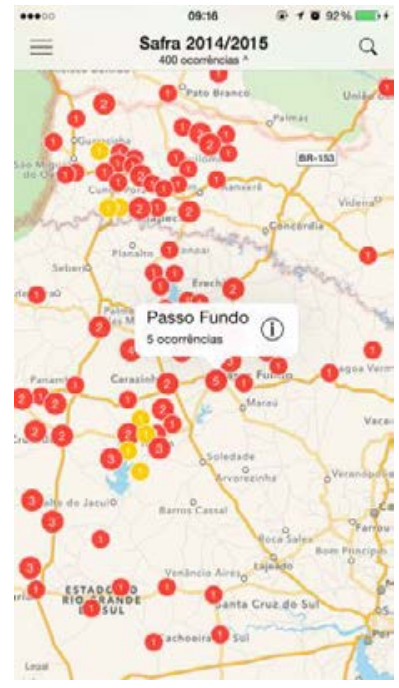

Figure 3. Selecting a city

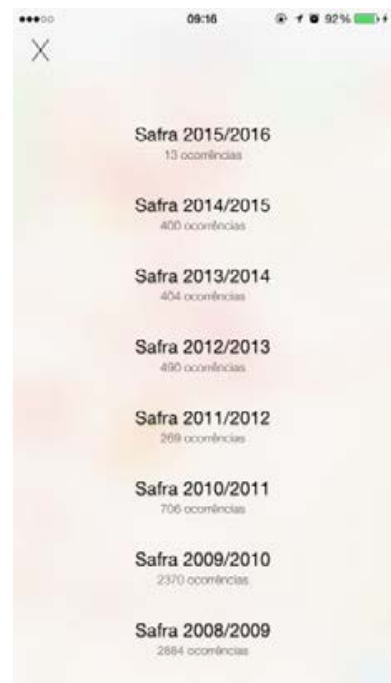

Figure 4. Selecting a different season

\subsection{Searching a City, Detailing of Observations and Notifications}

Looking at facilitate the access for specific information, disease occurrences are also presented through a list, where users can easily search for a particular city. This option is available tapping in the search icon on the main screen. Users can enter the name of the city wanted to search or scroll through the list, comparing and checking the total amount of occurrences by city and state.

By the map interface as well as the list, users can access detailed information about each observation by selecting the desired city. After selecting a specific city, a new screen presents all observations registered to that place, bringing information such as: occurrence date; plant phenological stage; person or entity who made the observation; and the laboratory who confirmed the infection by the fungus Phakopsora pachyrhizi. 
One of the great advantages of using mobile technologies on a disease dispersion system is the possibility to send alerts to users when an infection is registered in their region. The CAF mobile app sends push notifications using the Apple Push Notification Service (APNS) and Google Cloud Service (GCM) for users who opt-in to receive alerts.

\subsection{Distribution}

The application is available for download on the App Store and Play Store, which is accessible directly from any iOS and Android devices. Since the application was made available it has exceeded the mark of 4,200 unique downloads. The registered downloads come from different parts of the world and reveal the interest in this kind of information, not only by Brazilian producers and researchers, but also by the soybean market around the world.

\section{Conclusions}

The CAF mobile application keeps track of Asian soybean rust occurrences, in time and space, appearing as an important decision aid tool for the disease management. The application delivers crucial information by making use of real-time dispersion maps allowing the smooth tracking of the disease during the soybean growing season. Besides, it provides a valuable quantification of soybean rust intensity in different years and soybean producing areas in Brazil.

\section{References}

EMBRAPA. Doenças e Medidas de Controle. Technical Report Sistema de Produção n. 1, Embrapa Soja, Londrina, Brazil, 2001. Available at: http://www.cnpso.embrapa.br/producaosoja/doenca.htm.

Esker, P.D., Del Ponte, E.M., Martins, M., Kato, J., Siqueri, F.V., Silva, L.H., and Godoy, C.V. Effects of location and year on the temporal disease progress of Asian soybean rust in Brazil. In: 2007 APS/SON Joint meeting, San Diego, Phytopathology, 97:S33 (2007).

Godoy, C. V., Bueno, A. F., and Gazziero, D. L. P. Brazilian Soybean Pest Management and Threats to its Sustainability. Outlooks on Pest Management, 26:3 (2015), 113117.

Kim, K.S., Wang, T.C., and Yang, X.B. Simulation of apparent infection rate to predict severity of soybean rust using a fuzzy logic system. Phytopathology, 95 (2005), 11221131.

Roberts, M. J., Schimmelpfennig, D., Ashley, E., and Ivingston, M. The value of plant disease early-warning systems: a case study of USDA's soybean rust coordinated framework. Technical Report Econ. Res. Rep. n.18. USDA-ERS, Washington, DC, 2006.

Yorinori, J. T., Paiva, W. M., Frederick, R. D., Costamilan, L. M., Bertagnolli, P. F., Hartman, G. E., Godoy, C. V., and Nunes, J., JR. Epidemics of soybean rust (Phakopsora pachyrhizi) in Brazil and Paraguay from 2001 to 2003. Plant Dis. 89 (2005), 675-677. 